Keywords: $M C U, A R P, I S D P$

Retention: Permanent

\title{
Solvent Hold Tank Sample Results for MCU-12-488, MCU-12-489, MCU-12-490, MCU-12-491, MCU-12-492 and MCU-12-493: Quarterly Sample from October 2012
}

\author{
F. F. Fondeur \\ T. B. Peters \\ S. D. Fink
}

January 2013

Savannah River National Laboratory Savannah River Nuclear Solutions

Aiken, SC 29808

Prepared for the U.S. Department of Energy under

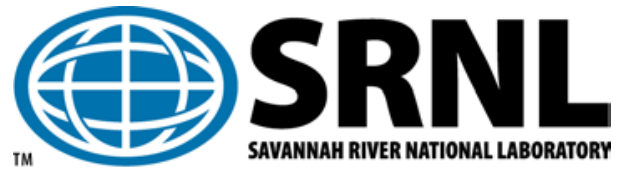
contract number DE-AC09-08SR22470. 
SRNL-STI-2012-00770

Revision 0

\section{DISCLAIMER}

This work was prepared under an agreement with and funded by the U.S. Government. Neither the U.S. Government or its employees, nor any of its contractors, subcontractors or their employees, makes any express or implied:

1. warranty or assumes any legal liability for the accuracy, completeness, or for the use or results of such use of any information, product, or process disclosed; or

2. representation that such use or results of such use would not infringe privately owned rights; or

3. endorsement or recommendation of any specifically identified commercial product, process, or service.

Any views and opinions of authors expressed in this work do not necessarily state or reflect those of the United States Government, or its contractors, or subcontractors.

\section{Printed in the United States of America}

Prepared for

U.S. Department of Energy 


\section{REVIEWS AND APPROVALS}

\section{AUTHORS:}

F. F. Fondeur, Co-author, SRNL/SASP

Date

T. B. Peters, Author, SRNL/SASP

Date

TECHNICAL REVIEW:

C. A. Nash, Technical Reviewer, SRNL/ACP

Date

APPROVAL:

S. D. Fink, SRNL/SASP, Manager

Date

S. L. Marra, SRNL/E\&CPT Research Programs, Manager

Date

D. J. Martin, H Tank Farm Process Engineering

Date 


\section{EXECUTIVE SUMMARY}

Savannah River National Laboratory (SRNL) analyzed solvent samples from Modular Caustic-Side Solvent Extraction Unit (MCU) in support of continuing operations. A quarterly analysis of the solvent is required to maintain solvent composition within specifications. Analytical results of the analyses of Solvent Hold Tank (SHT) samples MCU-12-488, MCU-12-489, MCU-12-490, MCU-12-491, MCU-12-492 and MCU-12493 received 24 October 2012 are reported.

The results show that the solvent at MCU does not require an Isopar ${ }^{\circledR} \mathrm{L}$ addition, but it will require addition of trioctylamine.

SRNL also analyzed the SHT sample for ${ }^{137} \mathrm{Cs}$ content and determined the measured value is within tolerance but is trending upward compared to the ${ }^{137} \mathrm{Cs}$ measurement made last year. 


\section{LIST OF ABBREVIATIONS}

ESS - Extraction, Scrub, and Strip

FTIR - Fourier transform infra-red spectroscopy

HPLC - High Performance Liquid Chromatography

ISDP - Integrated Salt Disposition Project

RSD - residual standard deviation

SHT - Solvent Hold Tank

SRNL - Savannah River National Laboratory

SVOA - Semi-Volatile Organic Analysis

TOA - trioctylamine 


\subsection{Introduction}

Solvent Hold Tank (SHT) samples are sent to Savannah River National Laboratory (SRNL) to examine solvent composition changes over time. ${ }^{1}$ On October 24, 2012, Operations personnel delivered six samples from the SHT (MCU-12-488 through MCU-12-493) for analysis. These samples are intended to verify that the solvent is within the specified composition range. The results from the analyses are presented in this document.

\subsection{Experimental Procedure}

Samples were received in p-nut vials containing $10 \mathrm{~mL}$ each. Once taken into the Shielded Cells, the samples were visually inspected, analyzed for $\mathrm{pH}$, and then combined. Samples were removed for analysis by density, semi-volatile organic analysis (SVOA), high performance liquid chromatography (HPLC), gamma counting, and FourierTransform Infra-Red spectroscopy (FTIR).

Details for the work are contained in a controlled laboratory notebook. ${ }^{2}$

\subsection{Results and Discussion}

Each of the six p-nut vials contained a single phase, with no apparent solids contamination or cloudiness. Table 1 contains the results of the analyses for the combined samples.

A duplicate density measurement of the organic phase gave a result of $0.840 \mathrm{~g} / \mathrm{mL}$ ( $0.27 \%$ residual standard deviation - RSD) at $18.4{ }^{\circ} \mathrm{C}$ (or $0.834 \mathrm{~g} / \mathrm{mL}$ at $25^{\circ} \mathrm{C}$ when corrected for temperature). Using the density as a starting point, we know that the Isopar ${ }^{\circledR} \mathrm{L}$ should be slightly higher than nominal and the other components should be slightly lower than nominal.

The results as a whole are internally consistent. All measurements indicate Isopar ${ }^{\circledR} \mathrm{L}$ higher than nominal, and Modifier* lower than nominal. The extractant result is within $0.5 \%$ of the nominal value with a lower value expected from Isopar ${ }^{\circledR} \mathrm{L}$ dilution. For example, using the measured density as well as the Isopar ${ }^{\circledR} \mathrm{L}$ and Modifier concentrations from the FTIR results, we calculate an extractant concentration of 7896 $\mathrm{mg} / \mathrm{L}$. This value is within the analytical uncertainty of the reported HPLC value. There are several sources of errors that affect the accuracy of the values reported in Table 1 . If dilution (excess Isopar ${ }^{\circledR} \mathrm{L}$ ) was the only effect on composition, then $95 \%$ of the nominal composition of the remaining components is expected if we have $3 \%$ excess Isopar $^{\circledR} \mathrm{L}$. If

\footnotetext{
* Modifier is (1-(2,2,3,3-tetrafluoropropoxy)-3-(4-sec-butylphenoxy)-2-propanol, also known as Cs-7SB, is added to increase solubility of the extractant.
} 
the sample has a $4 \%$ excess Isopar ${ }^{\circledR} \mathrm{L}$, then $91 \%$ of the nominal composition of the remaining component is expected. The same conclusion can be reached if the Modifier concentration decreased by $9 \%$, the Isopar ${ }^{\circledR} \mathrm{L}$ concentration will increase by $104 \%$ of its nominal value. As indicated in Table 1, the Modifier and Isopar ${ }^{\circledR} \mathrm{L}$ concentrations are consistent within the noise of sample handling and methods uncertainties. The TOA have concentrations much lower than expected.

When compared to the MCU density target of $0.845 \mathrm{~g} / \mathrm{mL}$, there is no need to add an Isopar ${ }^{\circledR} \mathrm{L}$ trim. * However, it is advisable to add sufficient trioctylamine (TOA) to return the solvent composition to within specifications as that component has declined to about $53 \%$ of the concentration of the expected value ( $0.12 \mathrm{wt} \%$ of the solvent). The TOA measurement was performed twice, so the result is not an analytical aberration. TOA in the quarterly sample of August 2012 was found to be $45.1 \%$ of its nominal value at that time. This current sample was pulled after the addition of 50 gallons of full solvent but before the addition of 397 grams of TOA to the solvent on November 9, 2012. This loss rate is unexpectedly high and it may explain the appearance of residual peaks in the infrared difference spectrum of this solvent as shown in Figure 1. After subtracting the infrared spectrum of nominal CSSX solvent (S2-D2-YesBob-T-WI) from this solvent, the peaks at $1557 \mathrm{~cm}^{-1}, 1366 \mathrm{~cm}^{-1}$ and $1383 \mathrm{~cm}^{-1}$ ) remain which are not from any component of the nominal solvent. The bands at 1383 and $1366 \mathrm{~cm}^{-1}$ may be due to branching (molecules highly substituted with methyl groups). However, the band at $1557 \mathrm{~cm}^{-1}$ clearly indicates the presence of a molecular group that is best explained by the nitro group rather than an amide group. ${ }^{3}$ The nominal solvent component most likely to form a nitro group is the tert-butyl group on the extractant.

In addition to the organic analysis, SRNL measured the ${ }^{137}$ Cs activity of the solvent. See Table 2. This measurement is used as an indication of whether or not the solvent is being properly stripped of cesium. The analytical uncertainty is $5 \%$.

\footnotetext{
* Note that while freshly prepared MCU solvent has a target density of $0.852 \mathrm{~g} / \mathrm{mL}$, the MCU facility targets tries to maintain the solvent inventory at $0.845 \mathrm{~g} / \mathrm{mL}$ to allow longer operating periods before correcting for evaporation.
} 
Table 1. Sample Results for MCU-12-488/489/490/491/492/493 Composite

\begin{tabular}{|c|c|c|c|c|c|}
\hline Analysis & Method & LIMS \# & $\begin{array}{l}\text { Result } \\
(\mathrm{mg} / \mathrm{L})^{\#}\end{array}$ & $\begin{array}{c}\text { Nominal }^{*} \\
\text { Result } \\
(\mathrm{mg} / \mathrm{L})\end{array}$ & $\begin{array}{l}\% \text { of (Result } \div \\
\text { Nominal Result) }\end{array}$ \\
\hline Isopar $^{(B)} \mathrm{L}$ & SVOA & 300302119 & 600,000 & 589,000 & $102 \%$ \\
\hline Isopar ${ }^{(B)} \mathrm{L}$ & FTIR & NA & 595,762 & 589,000 & $101 \%$ \\
\hline Isopar ${ }^{(R)} \mathrm{L}$ & Density $^{*}$ & NA & 616,945 & 589,000 & $105 \%$ \\
\hline average & all & NA & 602,876 & 589,000 & $103 \%$ \\
\hline Modifier & SVOA & 300302119 & 210,000 & 254,000 & $82.7 \%$ \\
\hline Modifier & HPLC & 300295714 & 229,000 & 254,000 & $90.2 \%$ \\
\hline Modifier & FTIR & NA & 231,963 & 254,000 & $91.3 \%$ \\
\hline Modifier & Density $^{*}$ & NA & 214,151 & 254,000 & $84.3 \%$ \\
\hline average & all & NA & 220,913 & 254,000 & $87.1 \%$ \\
\hline trioctylamine & SVOA & 300302120 & 540 & 1,020 & $53.00 \%$ \\
\hline Extractant & HPLC & 300295714 & 8040 & 8,000 & $100.5 \%$ \\
\hline $\begin{array}{l}\text { Density } \\
(\mathrm{g} / \mathrm{mL})\end{array}$ & $\begin{array}{c}\text { Direct } \\
\text { measurement }\end{array}$ & NA & 0.8344 & 0.852 & $97.9 \%$ \\
\hline
\end{tabular}

" Analytical uncertainty is $20 \%$ for SVOA and 10\% for HPLC. FTIR analytical uncertainty is $15 \%$ for Isopar ${ }^{\circledR} \mathrm{L}$ and $10 \%$ for Modifier. Density results from the average of replicate volumetric trials typically have a percentage standard deviation of $<1 \%$ between each value and the average.

* Nominal value is the expected value for freshly prepared solvent with a target density $=0.852 \mathrm{~g} / \mathrm{mL}^{4} \quad \mathrm{NA}=$ not applicable

Table 2. ${ }^{137} \mathrm{Cs}$ in the CSSX Solvent

\begin{tabular}{|c|c|}
\hline Analyte & Result (dpm/mL) \\
\hline${ }^{137} \mathrm{Cs}$ & $3.34 \mathrm{E}+06$ \\
\hline
\end{tabular}

This result is $1.9 \mathrm{x}$ higher than the previous measurement ${ }^{5}$ and it is $5.2 \mathrm{x}$ higher than the June 2012 quarterly sample. ${ }^{6}$ A better perspective of this data is the more global view shown in Figure 2. As can be seen the current data is within historical value but the last three data points indicate the start of an upward trend. A trend that is larger than the analytical source of error (5\%) but within previous data. Further mathematical analysis is needed to determine correlation with data from other streams such as the CWT samples. 


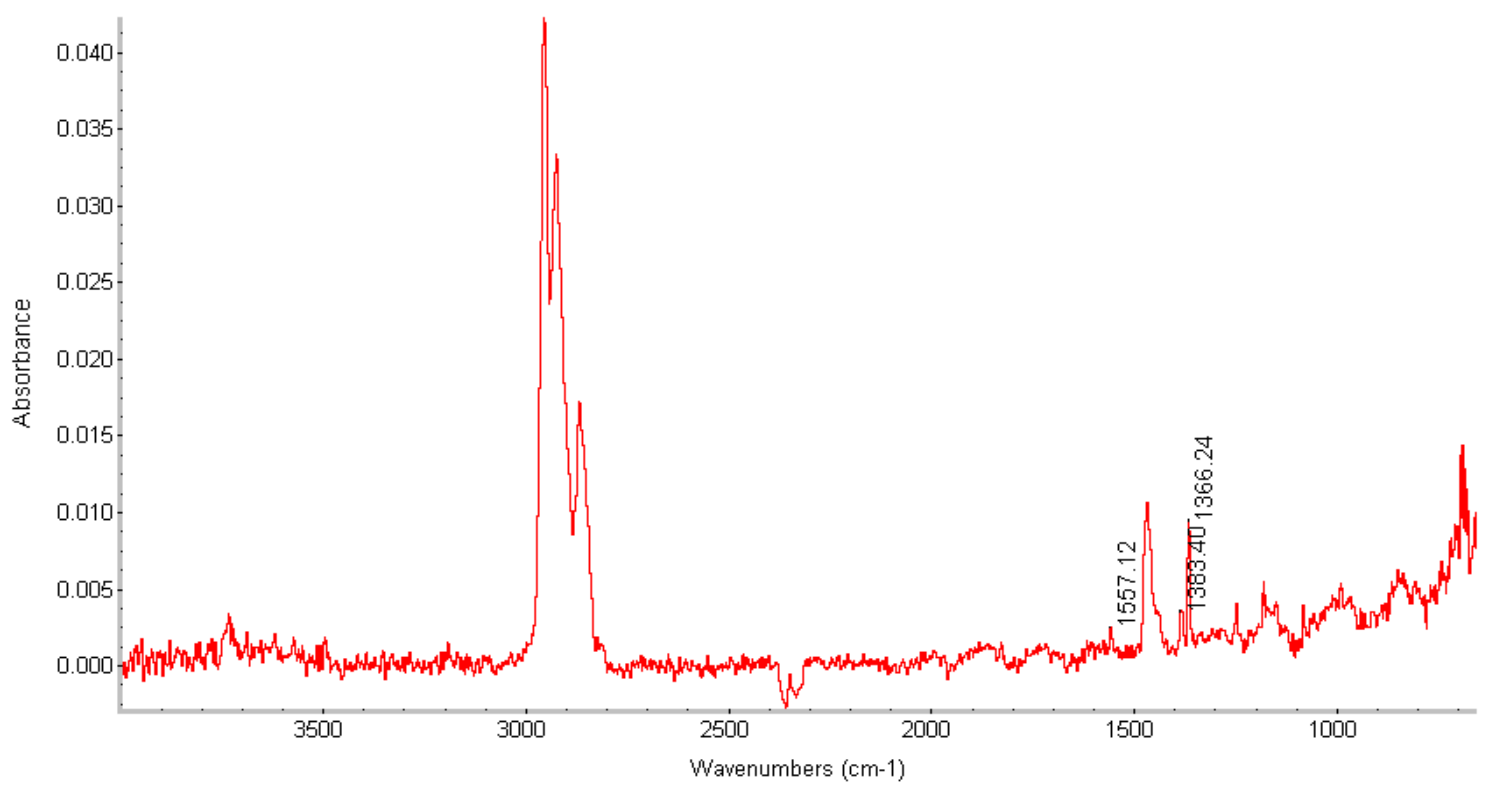

Figure 1. The difference spectrum obtained by subtracting the infrared spectrum of nominal CSSX (S2-D2-YesBob-T-WI) from SHT 488 to 493.

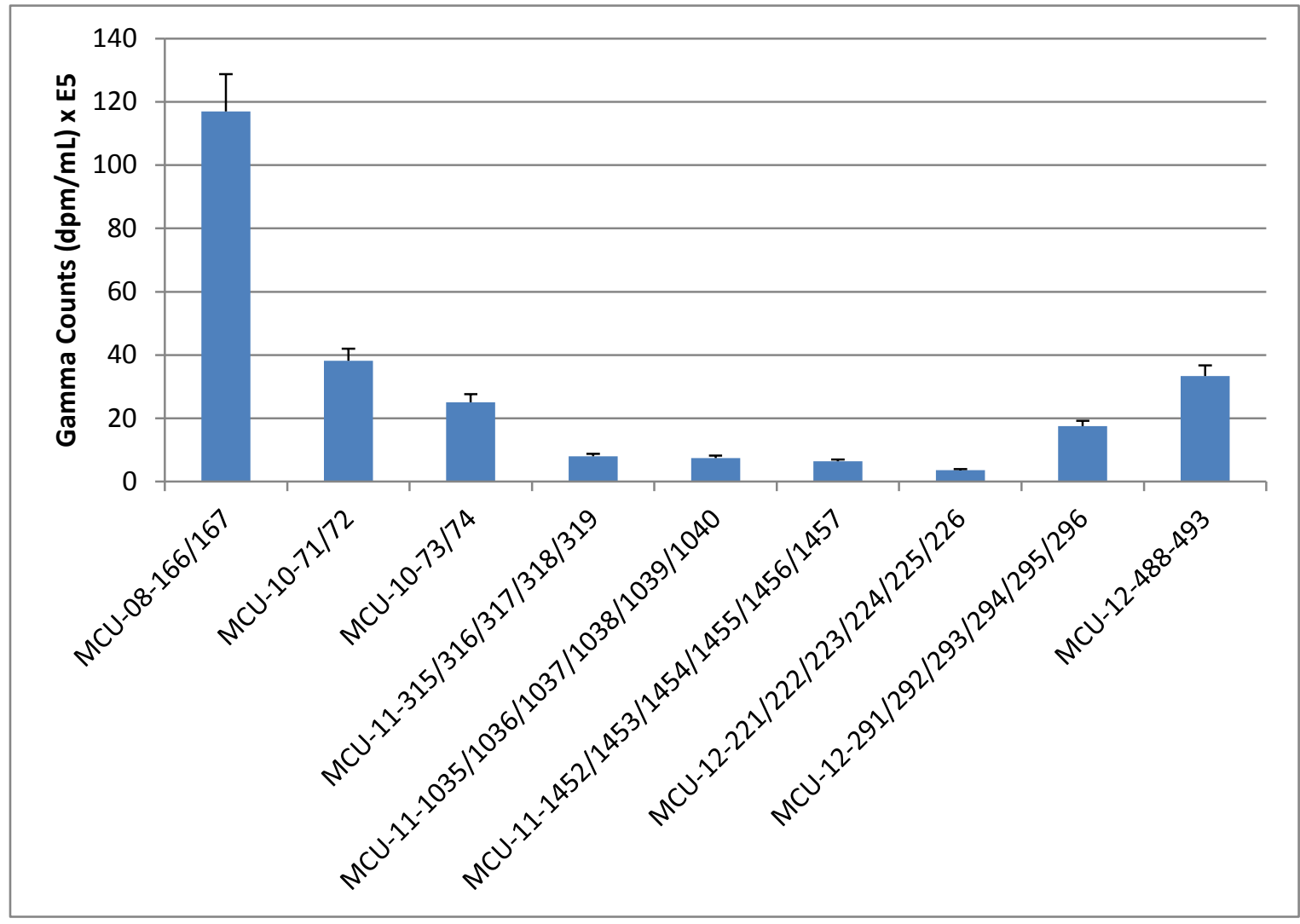

Figure 2. The gamma count of selected SHT samples. One standard deviation is $10 \%$. 


\subsection{Conclusions}

As with the previous solvent sample results, ${ }^{6}$ these analyses indicate that the solvent does not require Isopar ${ }^{\circledR}$ L trimming at this time. However, addition of TOA is warranted.

These findings indicate that the protocols for solvent monitoring and control are yielding useful information. The deviation in the TOA concentration since the last analysis indicates continued periodic (i.e., quarterly) monitoring is recommended. 


\subsection{References}

${ }^{1}$ W. M. Matthews, HLW-CRF-10006, Rev. 0, May 18, 2010.

2 T. B. Peters, “ISDP4”, SRNL-NB-2011-00027, February 18, 2011.

${ }^{3}$ Emersom S. Lima, Paolo Di Mascio, Homero Rubbo,| and Dulcineia S. P. Abdalla, "Characterization of Linoleic Acid Nitration in Human Blood Plasma by Mass Spectrometry”, Biochemistry 2002, 41, 1071710722.

${ }^{4}$ L.H. Delmau, J. F. Birdwell Jr., P. V. Bonnesen, L. J. Foote, T. J. Haverlock, L. N. Klatt, D. D. Lee, R. A. Leonard, T. G. Levitskaia, M. P. Maskarinec, B. A. Moyer, F. V. Sloop Jr., B. A. Tomkins, “Caustic-Side Solvent Extraction: Chemical and Physical Properties of the Optimized Solvent”, October 2002, ORNL/TM-2002/190.

${ }^{5}$ F. F. Fondeur, T. B. Peters, and S. D. Fink, "Quarterly Solvent Hold Tank Sample Results For August 2012: Samples MCU-12-291, MCU-12-292, MCU-12-293, MCU-12-294, MCU-12-295, and MCU-12296”, SRNL-STI-2012-00637, October 2012.

${ }^{6}$ T. B. Peters, F. F. Fondeur, S. D. Fink, "Solvent Hold Tank Sample Results for MCU-11-1035, MCU-111036, MCU-11-1037, MCU-11-1038, MCU-11-1039 and MCU-11-1040”, SRNL-STI-2011-00593, October 2011. 


\section{Distribution:}

K. M. Fox, 999-W

S. D. Fink, 773-A

C. C. Herman, 999-W

S. L. Marra, 773-A

F. M. Pennebaker, 773-42A

M. T. Keefer, 704-56H

D. J. Martin, 241-152H

B. A. Gifford, 704-56H

Q. L. Nguyen, 241-152H

S. G. Campbell, 992-5W

T. B. Peters, 773-42A

C. A. Nash, 773-42A

F. F. Fondeur, 773-A

P. R. Jackson, 703-46A 